\title{
LEPIDOPTERAN PESTS ASSOCIATED WITH THE SOYBEAN CULTIVARS PHENOLOGY
}

\author{
LEPIDOPTEROS-PRAGA ASSOCIADOS COM ESTÁGIOS FENOLÓGICOS \\ DE CULTIVARES DE SOJA
}

\author{
Eliane CARNEIRO ${ }^{1}$; Luciana Barboza SILVA ${ }^{\mathbf{1}}$; Alexandre Faria da SILVA ${ }^{\mathbf{1}}$; \\ Gleidyane Novais LOPES ${ }^{1}$; Bruno Ettore PAVAN ${ }^{2}$; \\ Raimundo Henrique Ferreira RODRIGUES ${ }^{1}$; Diego Tavares CARVALHINHO ${ }^{1}$; \\ Diego Fabio MIELEZRSKI ${ }^{1}$ \\ 1. Universidade Federal do Piauí, Campus Professora Cinobelina Elvas (UFPI/CPCE), Bom Jesus, PI, Brasil. \\ gnlopesm@hotmail.com; 2. Faculdade de Engenharia, Universidade Estadual Paulista (UNESP), Ilha Solteira, SP, Brasil.
}

\begin{abstract}
Lepidopteran pests are one of the major constraints to the soybean production potential, whose defoliating caterpillars can occur throughout the crop cycle causing serious damage. Therefore, the objective was to study the population fluctuation of lepidopteran pests and the association of species with the growth stages of soybean cultivars in the Cerrado of Piaui State, Brazil, in order to obtain data to support integrated pest management in the crop. The experiments had as a source of variation thirteen cultivars with fourteen evaluations. The design used was completely randomized in split plots being the cultivars plots and subplots the cultivars phenological stages. The monitoring was conducted by shake-cloth method at random points. Weekly samplings were performed. Generally, species of lepidopteran pests occurred in all soybean phenological stages, especially Chrysodeixis includens and Anticarsia gemmatalis that were present from the beginning to the end of the crop.
\end{abstract}

KEYWORDS: Monitoring. Integrated pest management. Infestation.

\section{INTRODUCTION}

Soybean [Glycine $\max (\mathrm{L}$.) Merrill] is one of the most cultivated crops in the world, being one of important economy commodities. The increase in crop yields is basically linked to the investment in biotechnology, mainly due to the development of crops adapted to different regions, resistance to pests and diseases, the insecticides and fungicides molecules more efficient and selective and the soil management (FREITAS, 2011).

The greater limitations to the production of soybeans are potential pests and diseases, being this crop the primary host of several species of insect pests that cause damage at different crop stages. The plant bugs (Hemiptera: Pentatomidae) and the complex of defoliating caterpillars [e.g. Spodoptera spp., Heliothis virescens (Fabricius), Anticarsia gemmatalis Hübner, Helicoverpa zea (Boddie), Chrysodeixis includens (Walker) and Helicoverpa armigera (Hübner) complex (Lepidoptera: Noctuidae)] are considered the main pests of soybean in Brazil (CZEPAK et al., 2013). The damage can reduce significantly the leaf area and cause economic damage, especially when they occur during the crop reproductive stage (CARVALHO et al., 2012; MOSCARDI et al., 2012).

The Integrated Pest Management-IPM combines chemical, physical and biological control measures where they are listed after the monitoring of the area, with the detection of the insect pests population above the level of economic damage (PRAÇA et al., 2006). The level of economic damage must be monitored by means of sampling methods such as the shake-cloth (HOFFMANNCAMPO et al., 2000). The soybean IPM recommended to arthropods and mollusks that strike this crop's leaves is the set of all available technologies that, adopted together with the crop development, aims to keep the soybean agroecosystem as close as possible to an ecological balance (HOFFMANN-CAMPO et al., 2012).

Although there are many benefits in the IPM, its practice has been ignored by producers, who rely on the chemical control with broad spectrum of action insecticides mixed with herbicides for weed desiccation, or in postemergence situations and also on the occasion of fungicide applications, which has generated high selection pressure, with insects less susceptible to insecticide molecules and the increase of the population levels of secondary pests (EMBRAPA, 2013). Thus, it is important to emphasize the use of different control methods as biological control aimed at the preservation of the complex of natural enemies in the agro-ecosystem (natural biological control), through the careful use of selective insecticides, and inundative releases of natural 
enemies in crops (applied biological control) (HOFFMANN-CAMPO et al., 2012). Another way to reduce the damage caused by insect pests is the use of more herbivory-resistant cultivars. Plants can be considered susceptible or resistant, and this resistance against herbivory is a result of several strategies that plants use to make themselves less attractive in order to hinder the possibility of being found; or defend themselves, becoming an unsuitable food for insects, or even survive, through mechanisms that can be called tolerance or overcompensation (CINGOLANI et al., 2005; MACDONALD; BACK, 2005). Therefore, the objective was to evaluated the population fluctuation of lepidopteran pests and the association of species with the growth stages of soybean cultivars in the Cerrado of Piaui State, Brazil, in order to obtain data to support integrated pest management in the crop.

\section{MATERIAL AND METHODS}

The experiment was conducted in the agricultural year 2014/2015 at the São João Farm, located on Pirajá hills, in the city of Currais, Piauí,

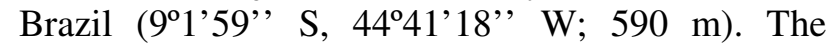
region climate according to Köppen classification is Aw, tropical, rainfall and average annual temperature of $986 \mathrm{~mm}$ and $26.4{ }^{\circ} \mathrm{C}$ respectively.

The soil of the experimental area is sandy, with the following characteristics: $\mathrm{pH}\left(\right.$ in $\left.\mathrm{H}_{2} \mathrm{O}\right)=$ $6.0 ; \mathrm{K}: 40 \mathrm{mg} \mathrm{dm}^{-3} ; \mathrm{P}=6,9 \mathrm{mg} \mathrm{dm}^{-3} ; \mathrm{Ca}=2,8 \mathrm{cmol}_{\mathrm{c}}$ $\mathrm{dm}^{-3} ; \mathrm{Mg}=1,0 \mathrm{cmol}_{\mathrm{c}} \mathrm{dm}^{-3} ; \mathrm{Al}=0,0 \mathrm{cmol}_{\mathrm{c}} \mathrm{dm}^{-3} ;$ $\mathrm{H}+\mathrm{Al}=1,73 \mathrm{cmol}_{\mathrm{c}} \mathrm{dm}^{-3}$; sum of bases $(\mathrm{SB})=3.9$; cationic exchange capacity $(\mathrm{CEC})=5.6 ; \mathrm{V}: 69.0 \%$ aluminum saturation $(\mathrm{m})=0.0 \%$ and $1.60 \mathrm{~g} \mathrm{~kg}^{-1}$ of organic matter $(\mathrm{OM})$.

The experiments had as a variation source thirteen soybean cultivars ['BRS 333', 'FT Campo Novo', 'FT Paragominas', 'M 8766 RR', 'M 9144', 'P 99 RR 03', 'P 99 RR 09', 'Pampeana 20', 'Pampeana 30' (RR Occasional Glyphosate resistance event), 'BRS Carnaúba', 'BRS Sambaiba', 'M 9359', 'Pampeana 10' (Convencional no event related)], with fourteen evaluations. The design was completely randomized in split plots being the cultivars plots and subplots the cultivars phenological stages. Each experimental plot consisted of 10 lines with $5 \mathrm{~m}$ long lines, with $0.45 \mathrm{~m}$ spacing; and 2 peripheral lines used as a border and in other ones weekly sampling were conducted from the vegetative stage V3 to the crop maturation stage (V3 to V7, vegetative stage, and $\mathrm{R} 1$ to $\mathrm{R} 8$, reproductive).

The monitoring was performed by the shake-cloth method at random points, weekly samplings were performed, insects collected, properly labeled and taken to the Planting Science Laboratory of Federal University of Piauí (UFPI/CPCE) for identification. Only caterpillars were found in the samples. Insecticide applications were carried out in order to reduce the population of insect pests according to the indicated treatments (Table 1).

Table 1. Insecticides applications and doses used in the control of soybean pests during the crop cycle.

\begin{tabular}{|c|c|c|c|c|c|c|c|c|}
\hline Order & Inseticides ar & ses L & ${ }^{-1}$ or $\mathrm{g} \mathrm{ha}^{-1}$ & & & & & \\
\hline 1 & Chlorpyrifos & 0.98 & & & & & & \\
\hline 2 & Chlorpyrifos & 0.98 & & & & & & \\
\hline 3 & Methomyl & 1.19 & VPN-HzSNPV & 0.20 & B.thuringiensis & 0.50 & & \\
\hline 4 & Methomyl & 1.49 & $\begin{array}{l}\text { Imidacloprid+Beta- } \\
\text { Cyfluthrin }\end{array}$ & 0.81 & & & & \\
\hline 5 & $\begin{array}{l}\text { Benzoat } \\
\text { Emamectin }\end{array}$ & 0.25 & Lambdacialotrin & 0.06 & & & & \\
\hline 6 & Tiodicarb & 0.35 & Teflubenzurom & 0.15 & Abamectin & 0.4 & Piriproxifem & 0.002 \\
\hline 7 & Abamectin & 0.20 & $\begin{array}{l}\text { Acetamiprid+Alpha- } \\
\text { cypermethrin }\end{array}$ & 0.39 & & & & \\
\hline
\end{tabular}

*In line, the mixtures used by application

The monitoring data were transformed by root $(\mathrm{x}+0.5)$ and it was carried out analysis of variance per caterpillar species, in which the significances of the mean squares were tested. When the cultivar interaction versus the evaluation (sample) was significant, the interaction deployment took place the average test was conducted by the Tukey method at $5 \%$ probability. These procedures were performed with the aid of the statistical software SAS® (SAS, 1999).

In the analysis of variance each species evaluation was considered a response variable, so that the significance among cultivars was obtained for all evaluations in several caterpillar species. After this initial analysis all not significant variables responses were cast aside, so that from the 98 initial 
variables responses there were 22 remaining, performed on the statistical software SAS® (SAS, 1999). With 22 significant variables responses a new analysis of variance was conducted aiming at obtaining the matrices of variances and residual covariances among them. Then it is possible to proceed with multivariate analyzes for the 22 evaluations of several species with the purpose of comparing the cultivars taking into account all significant evaluations. Therefore, after initial analysis, the multivariate analysis of cultivars behavior distances by Mahalanobis distance was carried out. Such procedure is the most appropriate according to Cruz et al. (2004), since this measure considers the residual correlations among the characters studied, leading to a measuring free of scale and collinear influences. With the matrix of distances between cultivars in hands, the Tocher's optimization and Ward's hierarchical clustering methods were obtained for the comparisons between methods and genetic materials. Then the Canonical variables were analyzed for the discrimination of major evaluations species that cause differentiation among cultivars. The statistical analyzes at a further moment and multivariate analyzes were performed on GENES software (CRUZ, 2006).

\section{RESULTS AND DISCUSSION}

Seven species of Lepidoptera were monitored over the cycle of 13 soybean cultivars. Population levels varied throughout the crop cycle considering the applications of insecticides. Generally, species of lepidopteran pests occurred in all soybean phenological stages, especially Chrysodeixis includens and Anticarsia gemmatalis which were present from the beginning to the end of the crop.

After each application of insecticide in different crop phenological stages, there was a reduction in the number of caterpillar (Figure 1). Clearly it is difficult to control $C$. includens because during the vegetative stage of soybean up to R6 stage five applications of insecticides took place, keeping other pests below the damage level, while $C$. includens still had high levels of infestation. Mistaken applications of insecticides, and at inappropriate time, made together with herbicides and fungicides in tank mixtures have unbalanced the microenvironment and the productive system allowing populations of secondary pests grow exponentially, becoming the soybean crops key pests (BUENO et al., 2007, 2010; HOFFMANNCAMPO et al., 2012). The control of $C$. includens has been considered difficult because it is a species more tolerant to the doses commonly used $A$. gemmatalis (SOSA-GÓMEZ et al., 2003; CRIALESI-LEGOR et al., 2014). Another challenge in controlling this pest it in its habit, since the caterpillars are usually housed in the lower third of the plants, thus, protected from the insecticide action, especially when the culture is closed (SOSAGOMEZ, 2006).

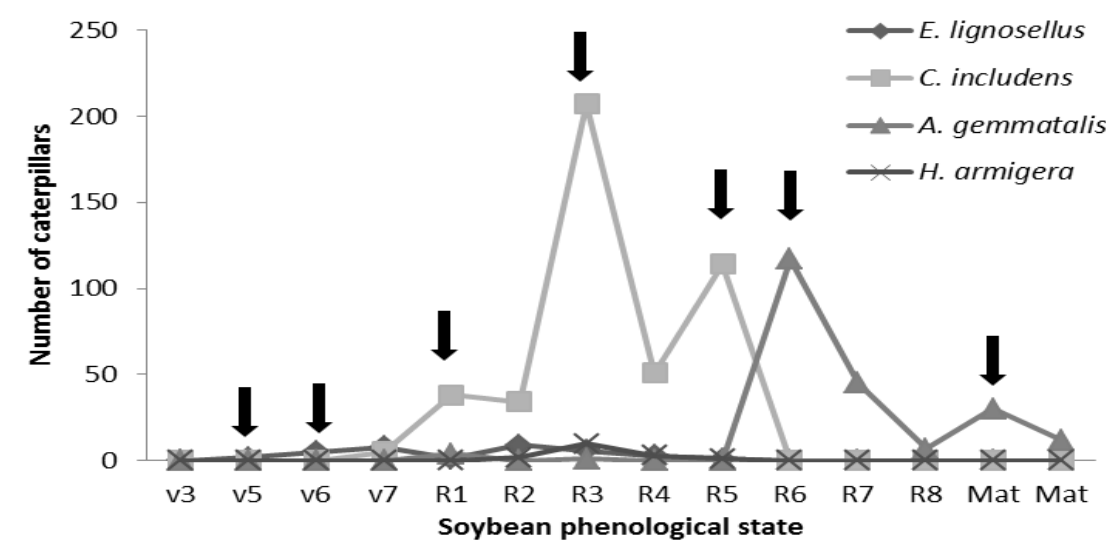

Figure 1. Lepidopteran pest population variation in relation to insecticide application at different phenological stages of 'P 99 RR 09' soybean. The arrows represent the insecticide applications.

The stages with higher occurrence of pest were $\mathrm{R} 1$ to $\mathrm{R} 4$, which verified the presence of all identified species (Table 2). The soybean stages in which it was observed an increase in population level were from R3 (beginning of pod formation) to R5 (beginning of grain filling). Similar results were found by Riffel et al. (2012) in studies on the sample density of defoliating velvetbean caterpillars where the highest population density was during the R5 stage. However, $C$. includens showed higher peaks in the reproductive stage (V7 - R6), while $A$. gemmatalis larger peaks occurred from the R5 stage 
until early maturation. The increase of a species population represented a reduction of other species which did not overlap. Different from the results found by Marsaro Jr. et al. (2010) where $C$. includens prevailed over A. gemmatalis.

Table 2. Presence and absence of lepidopteran pests of soybean in different crop stages of the 'P 99 RR 09' cultivar.

\begin{tabular}{|c|c|c|c|c|c|c|c|c|c|c|c|c|c|c|}
\hline \multirow{2}{*}{ Caterpillar species } & \multicolumn{14}{|c|}{ Soybean phenological state } \\
\hline & V3 & V5 & V6 & V7 & $\mathrm{R} 1$ & $\mathrm{R} 2$ & R3 & $\mathrm{R} 4$ & $\mathrm{R} 5$ & R6 & R7 & $\mathrm{R} 8$ & Mat & Mat \\
\hline \multicolumn{15}{|l|}{ Spodoptera frugiperda } \\
\hline \multicolumn{15}{|l|}{ Spodoptera cosmioides } \\
\hline \multicolumn{15}{|l|}{ Helicoverpa armigera } \\
\hline \multicolumn{15}{|l|}{ Elasmopalpus lignosellus } \\
\hline \multicolumn{15}{|l|}{ Chrysodeixis includens } \\
\hline Anticarsia gemmatalis & & & & & & & & & & & & & & \\
\hline
\end{tabular}

\section{Spodoptera eridania}

It is possible to note that, for all the species the interaction of cultivar and evaluation was significant, so that the different cultivars have different levels of infestation by the phenological stages. Consequently, the cultivars did not show the same response to infestation during the different crop phenological stages (Table 3).

Table 3. Summary of the analyzes of variance for seven caterpillars in different soybean crop phenological stages.

\begin{tabular}{|c|c|c|c|c|c|c|c|c|}
\hline \multirow{2}{*}{$\mathrm{FV}$} & \multirow{2}{*}{ G.L } & S. frugiperda & S. cosmioides & H. armigera & E. lignosellus & C. includens & A. gemmatalis & S.eridania \\
\hline & & \multicolumn{7}{|c|}{ Mean squares } \\
\hline Cultivar (C) & 12 & $0.0048^{\mathrm{ns}}$ & $0.0239 * *$ & $0.1005^{* *}$ & $0.3093^{* *}$ & $3.969 * *$ & $2.0727 * *$ & $0.0343 *$ \\
\hline Error a between & 36 & 0.0035 & 0.0195 & 0.0458 & 0.0226 & 0.448 & 0.2893 & 0.0233 \\
\hline Error a in & 52 & 0.0026 & 0.0102 & 0.0356 & 0.0273 & 0.430 & 0.5768 & 0.0127 \\
\hline $\mathrm{C} \times \mathrm{A}$ & 156 & $0.0035^{* *}$ & $0.0203^{*}$ & $0.1061 * *$ & $0.0488 * *$ & $1.092 * *$ & $0.7649 * *$ & $0.0217 *$ \\
\hline Error b between & 507 & 0.0024 & 0.0155 & 0.0524 & 0.0356 & 0.441 & 0.3110 & 0.0163 \\
\hline Error $b$ in & 676 & 0.0030 & 0.0135 & 0.0426 & 0.0391 & 0.254 & 0.1912 & 0.0143 \\
\hline Average & & 0.713 & 0.733 & 0.825 & 0.77 & 1.568 & 1.149 & 0.729 \\
\hline $\mathrm{CV} \%$ & & 7.65 & 15.84 & 25.02 & 25.67 & 32.13 & 38.04 & 16.41 \\
\hline
\end{tabular}

${ }^{\mathrm{ns}}$ not significant, $* * *$ significant at $5 \%$ and $1 \%$ respectively by F-test

In the deployment of the analysis of variance for all studied species, it was observed that in general from the fifth (R1) to the tenth (R6) evaluations were those that best differentiate the cultivars for most species except for A. gemmatalis and $S$. eridania which evaluations at the end of the cycle provided better differentiation among the cultivars. Table 4 shows the deployment of the analysis of variance only for $H$. armigera as an example of what was done for other species.

The occurrence of $H$. armigera was registered from the fifth (R1) to the ninth (R5) evaluations in all cultivars with the highest average (3.0) observed in the seventh (R3) evaluation for the cultivar 'BRS Carnaúba'. However, the presence of this species was found in the fourth evaluation (V7) in the cultivar ' $\mathrm{P} 99 \mathrm{RR} 09$ ' and in the tenth evaluation in the cultivar 'Pampeana 10' (Table 4). Species such as Heliothis and Helicoverpa often consume soy pods (HOFFMANN-CAMPO et al., 2012), which explains a greater frequency of $H$. armigera from the R1 stage of soybeans on. They directly affect the productivity by causing direct damage, ie, damage for the pods and grains. 
Moreover, by staying on the lower part of the plant, they are less noticeable, protected, and therefore, are less vulnerable to insecticide spray (FORMENTINI et al., 2015).

Table 4. Deployment of interaction between the cultivars and the evaluations carried out in the cultivars phenological stages based on the occurrence of $H$. armigera.

\begin{tabular}{llllllll}
\hline \multirow{2}{*}{ Cultivars } & \multicolumn{7}{c}{ Evaluations } \\
\cline { 2 - 8 } & $4^{*}$ & 5 & 6 & 7 & 8 & 9 & 10 \\
\hline BRS 333 RR & $0 \mathrm{bA}$ & $0.21 \mathrm{abAB}$ & $1.05 \mathrm{aA}$ & $1.05 \mathrm{aAB}$ & $0.57 \mathrm{abA}$ & $0.43 \mathrm{abA}$ & $0 \mathrm{bB}$ \\
BRS Carnaúba & $0 \mathrm{bA}$ & $0.28 \mathrm{bAB}$ & $0.85 \mathrm{bAB}$ & $3.0 \mathrm{aA}$ & $0.57 \mathrm{bA}$ & $0 \mathrm{bA}$ & $0 \mathrm{bB}$ \\
BRS Sambaíba & $0 \mathrm{cA}$ & $0.21 \mathrm{bcAB}$ & $0.93 \mathrm{abAB}$ & $1.5 \mathrm{aAB}$ & $0.45 \mathrm{abcA}$ & $0.1 \mathrm{bcA}$ & $0 \mathrm{cB}$ \\
FTS Campo Novo RR & $0 \mathrm{bA}$ & $0 \mathrm{bB}$ & $0.21 \mathrm{abAB}$ & $1.25 \mathrm{aAB}$ & $0.31 \mathrm{abA}$ & $0.1 \mathrm{bA}$ & $0 \mathrm{bB}$ \\
FTS Paragominas & $0 \mathrm{bA}$ & $0.1 \mathrm{bAB}$ & $0.44 \mathrm{bAB}$ & $1.5 \mathrm{aAB}$ & $0.1 \mathrm{bA}$ & $0.31 \mathrm{bA}$ & $0 \mathrm{bB}$ \\
M 8766 RR & $0 \mathrm{bA}$ & $0 \mathrm{bB}$ & $0.21 \mathrm{bAB}$ & $1.4 \mathrm{aAB}$ & $0.65 \mathrm{bA}$ & $0.1 \mathrm{bA}$ & $0 \mathrm{bB}$ \\
M 9144 RR & $0 \mathrm{aA}$ & $0.43 \mathrm{aAB}$ & $0.47 \mathrm{aAB}$ & $0.31 \mathrm{aB}$ & $0.43 \mathrm{aA}$ & $0.21 \mathrm{aA}$ & $0 \mathrm{aB}$ \\
M 9350 & $0 \mathrm{bA}$ & $0 \mathrm{bB}$ & $0.61 \mathrm{bAB}$ & $1.4 \mathrm{aAB}$ & $0.43 \mathrm{bA}$ & $0.1 \mathrm{bA}$ & $0 \mathrm{bB}$ \\
P 99 RR 03 & $0 \mathrm{bA}$ & $0.8 \mathrm{abA}$ & $0.9 \mathrm{abAB}$ & $1.3 \mathrm{aAB}$ & $0.4 \mathrm{abA}$ & $0.21 \mathrm{bA}$ & $0 \mathrm{bB}$ \\
P 99 RR 09 & $0.1 \mathrm{cA}$ & $0.43 \mathrm{bcAB}$ & $1.05 \mathrm{abA}$ & $1.4 \mathrm{aAB}$ & $0.21 \mathrm{bcA}$ & $0.21 \mathrm{cA}$ & $0 \mathrm{cB}$ \\
Pampeana10 & $0 \mathrm{cA}$ & $0 \mathrm{cB}$ & $0.6 \mathrm{bAB}$ & $1.45 \mathrm{abAB}$ & $0.1 \mathrm{cA}$ & $0.6 \mathrm{bcA}$ & $2.3 \mathrm{aA}$ \\
Pampeana20RR & $0 \mathrm{bA}$ & $0.1 \mathrm{bAB}$ & $0.1 \mathrm{bB}$ & $1.5 \mathrm{aAB}$ & $0.31 \mathrm{bA}$ & $0.55 \mathrm{abA}$ & $0 \mathrm{bB}$ \\
Pampeana30RR & $0 \mathrm{cA}$ & $0.1 \mathrm{bcAB}$ & $0.94 \mathrm{bAB}$ & $2.5 \mathrm{aAB}$ & $0.4 \mathrm{bcA}$ & $0.35 \mathrm{cA}$ & $0 \mathrm{cB}$ \\
\hline
\end{tabular}

*The evaluations 1 to 3 and 11 to 14 were not included in the table since their results were not significant;

Averages followed by the same capital letter in the column and small letter in the row do not differ statistically among each other by Tukey test $(\mathrm{P}>0.05)$.

The presence of E. lignosellus occurred in all cultivars of the second (V5) and the ninth (R5) evaluations, with the highest average (1.13) observed in the third (V7) evaluation for the cultivar 'Pampeana 20 RR'. The $C$. includens was observed in all cultivars from the fourth (V7) to the ninth (R5) evaluations, with the highest average (27.5) in the seventh evaluation (R3) for BRS Carnauba', with reduction in abundance in the tenth evaluation (R6). In the cultivar ' $M$ 9144' the occurrence of this species was observed from the first (V3) to the eleventh evaluation (R7), while in the late cultivars the occurrence was observed until the end of the crop cycle ('Pampeana 10', 'Pampeana 20 RR 'and' Pampeana $30 \mathrm{RR}$ '). The A. gemmatalis was observed from the fifth evaluation (R1) on in all cultivars, more frequently from the tenth evaluation (R6) on, whereas the highest average (17.36) was observed in the cultivar 'M 9350'. In the cultivar ' $M$ 9144' (early), it occurred throughout the crop cycle. The velvetbean caterpillar, A. gemmatalis, and the soybean looper, $C$. includens, are considered the main defoliating pests of soybean in Brazil, which strike can significantly reduce the leaf area and cause heavy economic damage, especially when that defoliation occurs during the reproductive period of culture (CARVALHO et al., 2012).

The occurrence of $S$. frugiperda was more evident at the sixth (R2) and seventh (R3) evaluations, with the highest average $(0.31)$ in the sixth evaluation (R2) for the cultivar 'BRS Carnaúba'. Spodoptera cosmioides occurred in all cultivars of the fifth (R1) and eighth (R4) with average evaluations between 0.1 to 1.05 , standing out the highest average (1.05) in the fifth review (R1) when the cultivar 'FTS Paragominas' was in stage R3. The cultivar 'M 9144 RR' was the only one that presented occurrence of caterpillars from the $1^{\text {st }}$ to the $10^{\text {th }}$ evaluations. Spodoptera eridania was observed from the eighth (R4) to the fourteenth (maturation) evaluations in virtually all cultivars with the highest average (0.75) in the cultivar 'FT Campo Novo RR' in the eleventh (R7) evaluation. Sporadic occurrences were observed for 'M 9144 RR' in the first (V3) and sixth (R2) evaluations, and 'BRS Carnauba' and 'Pampeana 30 RR' in the seventh (R3) evaluation. The caterpillars of Spodoptera complex (S. frugiperda, S. cosmioides and $S$. eridania) were more frequent in the reproductive phase. According to Moscardi et al. (2011) the frequency of occurrence of these pest species in soybean crops have greatly increased in recent years, causing major damage due to its great voracity. They are commonly found at the end of grain filling up to the culture senescence stage (DIDONET et al., 1998). One of the reasons for the occurrence of these species in soybeans can be the high polyphagia, Pogue (1995) lists over 100 host 
species, which means these species can survive and feed itself in many different groups of plants.

The cultivars with greater differentiation by Ward's clustering method were 'Pampeana 10' and 'M 9144 RR' showing that these cultivars have different infestation behavior when compared to the others in relation to the infestation of caterpillars species. Such cultivars are different from the others and from each other, showing that the infestations are differentiated in the crop phenological stages between the cultivars 'Pampeana 10' and 'M 9144 RR' and also between them and the others, since these genotypes were clustered with a distance of only $80 \%$ of the total, approximately (Figure 2).

The cultivars which had the lowest differentiation infestation behavior were 'M 9350' and 'Pampeana 30', demonstrating great infestation similarity of infestation of the different species and different phenological stages. Then with less differentiation and behavior there are the cultivars 'BRS Sambaíba' and 'M 8766 RR' that show little infestation diversity. The cultivars 'FTS Paragominas' and 'BRS Carnauba' were clustered with little discrepancies with the lower diversity cluster ('M 9350' and 'Pampeana 30'), demonstrating that these cultivars are similar in their infestation behavior.

The cultivars 'BRS 333 RR', 'P 99 RR 09' and 'P 99 RR 03' were clustered with little discrepancy with the second smaller cluster in terms of distance ('BRS Sambaíba' and 'M 8766 RR'), showing that such cultivars form a cluster of little diversity infestation behavior (Figure 2).
As for the cultivars 'FTS Campo Novo' and 'Pampeana 20', they formed a third cluster with little differentiation, however such cultivars cluster with the ones with littlest diversity before joining the larger discrepancy cultivars, showing thus that all cultivars, except for 'M 9144 RR" and "Pampeana 10", have similar behavior (Figure 2). These genotypes have mostly lower infestation rates demonstrating greater resistance or because the cultivars doesn't have a special preference for the caterpillars, whereas they may have lower levels of infestation or the infestation may occur at various growth stages. The defense mechanisms begin with the recognition by the host of exogenous signals from the pathogen. It continues with the transduction mechanisms of these signals and results in extensive reprogramming of plant cell metabolism which can activate defense mechanisms of the plant that can be structural and biochemical, previously or post formed (WALTERS et al., 2007). The structural mechanisms are physical barriers to penetration and/or colonization of the pathogen, whereas the biochemical mechanisms include substances capable of inhibiting the development of pathogenic or generate adverse conditions for the survival in tissues of the host (PASCHOLATI et al., 2008). These defense mechanisms can be observed at different defoliation levels among cultivars, caused by caterpillars attack, showing that resistance is a natural defense strategy for plants (DE BORTOLI et al., 2011; BUENO et al., 2011).

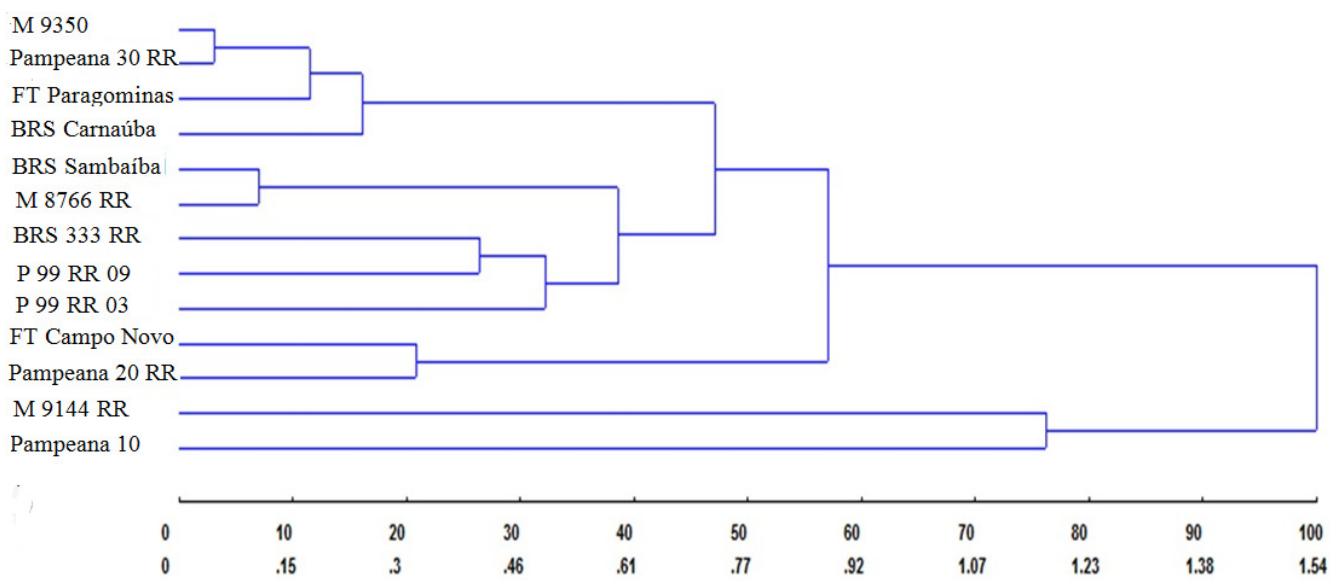

Figure 2. The dendrogram obtained by the Ward's hierarchical clustering method from the Mahalanobis distances matrices among thirteen soybean cultivars for the infestations behavior of seven caterpillar species on 22 evaluations at different crop phenological stages.

The Tocher's method segregated the cultivars into three clusters: the first one with eleven cultivars and the other two with only one cultivar (Table 5). Demonstrating the great differentiation of cultivars 'Pampeana 10' and 'M 9144 RR' from all others. And such cultivars also differ from each other whereas clusters 2 and 3 were the ones which showed the greatest divergence among the clusters. 
In general, the Tocher's method complemented the information obtained by the Ward's method, whereas Tocher separated the clusters allowing the segregation of diverse genetic material and Ward allowed the comparison between the materials in pairs, establishing the clusters hierarchy and allowing the selection of several cultivars within Torcher's cluster 1 .

Table 5. Clustering by the Tocher's method for thirteen soybean cultivars for infestation levels of seven caterpillar species in different crop phenological stages, from Mahalanobis' generalized distances.

\begin{tabular}{ll}
\hline Groups & Cultivars \\
\hline $\mathbf{1}$ & 'M 9350', 'Pampeana 30 RR', 'M8766 RR', 'FT Paragominas', 'BRS \\
& Carnaúba', 'P 99 RR 09', 'BRS Sambaiba', 'BRS 333 RR', 'P 99 RR 03', \\
& 'Pampeana 20 RR', 'FTS Campo Novo RR' \\
\hline $\mathbf{2}$ & 'Pampeana 10' \\
\hline $\mathbf{3}$ & 'M 9144 RR' \\
\hline
\end{tabular}

The scatter chart from Canonical variables made it possible to simplify the distances between cultivars in two variables, whereas the first one accumulated a percentage of the total distance of $94 \%$ and the second $4 \%$; both corresponding to $98 \%$ of the total variation among the cultivars (Figure 3). Again, it was observed that the cultivars 'Pampeana 10 ' and 'M 9144 RR' differed from the others, confirming the clusters obtained previously. The objective of the canonical variable analysis is the discrimination of the main evaluations of different caterpillars species and it enhanced the efficiency once the first two variables accumulated much of the total variance. It is possible to discard variables

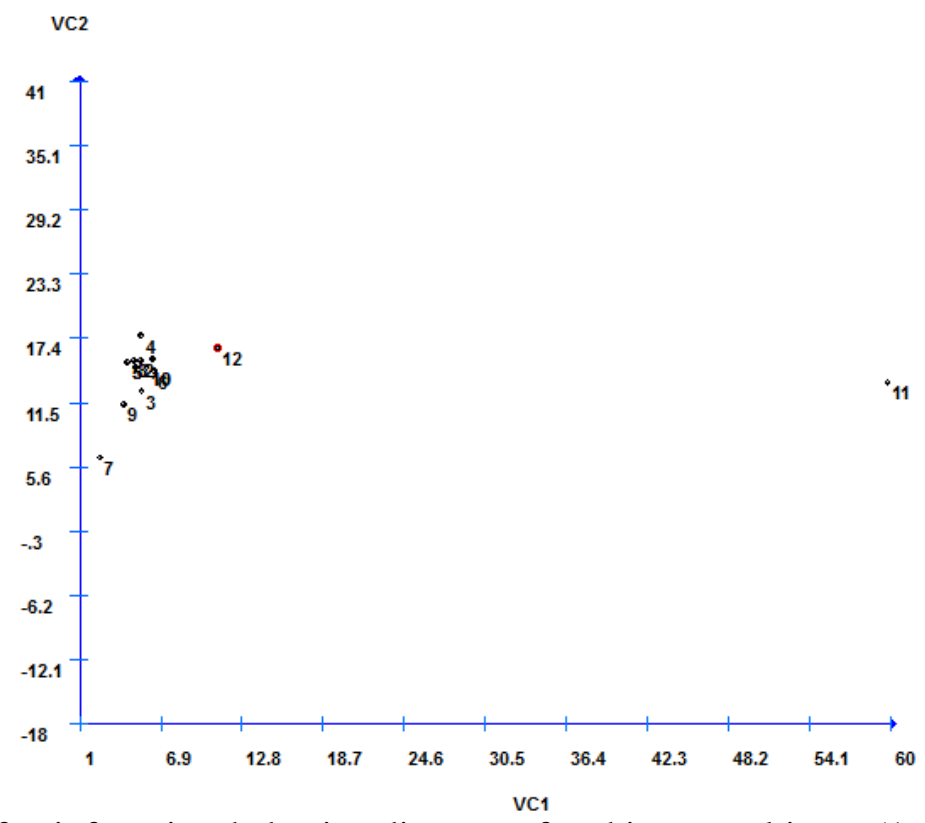

vc1 of evaluations in different caterpillars. The evaluations which less contributed to the differentiation of cultivars were 5,7 and 10 for $H$. armigera; and 6, 8, 11 and 14 for the species $C$. includes; and 11 for the species A. gemmatalis.

From the 98 initial assessments only 14 remained: E. lignosellus (3, 4 and 6), S. frugiperda (6), $H$ armigera (6), $S$. cosmioides (7), $C$ includens (9, 10 and 13) A. gemmatalis (10 and 13) and $S$. eridania (11 and 13). Consequently, the 14 phenological stages of this culture are significant to differentiate the behavior of infestation of caterpillars stages $3,4,6,7,9,10,11$ and 13 reducing by half the need for initial evaluations.

Figure 3. Scatter chart for infestation behavior distances for thirteen cultivars ( $1=$ 'BRS 333 RR', 2 'BRS Carnaúba', 3 'BRS Sambaíba', 4 'FTS Campo Novo RR', 5 'FTS Paragominas', 6 'M 8766 RR', 7 'M 9144 RR', 8 'M 9350', 9 'P 99 RR 03', 10 'P 99 RR 09', 11 'Pampeana 10', 12 'Pampeana 20 RR', 13 'Pampeana 30 RR') from Canonical variables.

In the canonical variable analysis it was observed the discrimination of the main evaluations of different caterpillars species which enhanced the efficiency once the first two variables accumulated much of the total variance, On the other hand, the evaluations which less contributed to the 
differentiation of cultivars were 5, 7 and 10 for the species $H$. armigera; and 6, 8, 11 and 14 for the species $C$. includens; and 11 for the species $A$. gemmatalis. Therefore, agronomic characteristics, greater resistance to diseases and pests, more adapted cultivars, as well as special soybean cultivars, human food type, free of lipoxygenase, which gives beans better flavor in order to produce grains that are more accepted by consumers, with better characteristics increasingly longed by breeders (SANTOS et al., 2011).

However, to obtain new soybean cultivars, studies on genetic divergence are necessary to better understand the existing diversity of both introduced cultivars and those adapted to a particular region. Santos et al. (2011) also found similarity pattern of soybean genotypes by the graphic dispersion of the canonical variables, which were consistent among themselves. For Abreu et al. (2004), this identification of contrasting genotypes by means of multivariate techniques and clusters is relevant to the breeding programs to be successful.

\section{CONCLUSIONS}

Seven species of Lepidoptera pests were identified throughout the soybean phenological stage.

The species of caterpillars found presented different behavior in relation to the cultivars and the phenological stages of soybean.

The use of insecticides was not efficient to control of $A$. gemmatalis and $C$. includens, demonstrating the importance of monitoring and using different management techniques to keep the population of lepidopteran pests below the level of economic damage.

RESUMO: Lepidópteros-praga estão entre os principais entraves ao potencial de produção de soja, cujas lagartas desfolhadoras podem ocorrer ao longo do ciclo da cultura, causando sérios danos. Portanto, o objetivo foi estudar a flutuação populacional de lepidópteros-praga e a associação dessas espécies com os estádios de crescimento de cultivares de soja no Cerrado do Estado de Piauí, a fim de obter dados para apoiar o manejo integrado de pragas na cultura. Os experimentos tiveram como fonte de variação treze cultivares com catorze avaliações. $\mathrm{O}$ delineamento utilizado foi inteiramente casualizado em parcelas subdivididas, sendo os cultivares as parcelas e as subparcelas os estádios fenológicos dos cultivares. O monitoramento foi realizado por meio do método de pano-de-batida em pontos aleatórios. Foram realizadas amostragens semanais. Em geral, espécies de lepidópteros-praga ocorreram em todos os estádios fenológicos da cultura da soja, especialmente Chrysodeixis includens e Anticarsia gemmatalis que estavam presentes desde o início até o final da cultura.

PALAVRAS-CHAVE: Monitoramento. Manejo Integrado de Pragas. Infestação.

\section{REFERENCES}

ABREU, F. B.; LEAL, N. R.; RODRIGUES, R.; AMARAL, J. R. A. T.; SILVA, D. J. H. Divergência genética entre acessos de feijão-de-vagem de crescimento indeterminado. Horticultura Brasileira, Brasília, DF, v. 22, p. 547-552, 2004. http://dx.doi:10.1590/S0102-05362004000300009.

BUENO, R. C. O de F.; PARRA, J. R. P.; BUENO, A. de. F.; MOSCARDI, F.; OLIVEIRA, J. R. G.; CAMILLO, M. F. Sem barreira. Revista Cultivar, v. 93, p. 12-15, 2007.

BUENO, A. F.; CORRÊA-FERREIRA, B. S.; BUENO, R. C. O. F. Controle de pragas apenas com o MIP. A Granja, v. 1, p. 76-79, 2010.

BUENO, A. F.; BATISTELA, M. J.; BUENO, R. C. O. F.; FRANÇA-NETO, J. B.; NISHIKAWA, M. A. N.; FILHO, A. L. Effects of integrated pest management, biological control and prophylactic use of insecticides on the management and sustainability of soybean, Crop Protection, v. 30, n. 7, p. 937-945, 2011. http://dx.doi:10.1016/j.cropro.2011.02.021.

CARVALHO, L. C.; FERREIRA, F. M.; BUENO, N. M. Importância econômica e generalidades para o controle da lagarta falsa-medideira na cultura da soja. Enciclopédia Biosfera, v. 8, n. 15, p. 1021, 2012. 
CINGOLANI, A. A.; POSSE, G.; COLLANTES, M. B. Plant functional traits, herbivore selectivity and response to sheep grazing in Patagonian steppe grasslands. Journal of Applied Ecology, v. 42, n. 1, p. 50-59, 2005. http://dx.doi: 10.1111/j.1365-2664.2004.00978.x.

CRIALESI-LEGORI, P. C. B.; DAVOLOS, C. C.; LEMES, A. R. N.; MARUCCI, S. C.; LEMOS, M. V. F.; FERNANDES, O. A.; DESIDÉRIO, J. A. Interação de proteínas Cry1 e Vip3A de Bacillus thuringiensis para controle de lepidópteros-praga, Brazilian Agricultural Research Corporation, v. 41, n. 11, p. 1643-1651, 2014. http://dx.doi.10.1590/S0100-204X2014000200001.

CRUZ, C. D. Programa Genes: análise multivariada e simulação, MG: Editora UFV, 2006.

CRUZ, C. D.; REGAZZI, A. J.; CARNEIRO, P. C. S. Modelos biométricos aplicados ao melhoramento genético, Viçosa: Editora UFV, 2004.

CZEPAK, C.; ALBERNAZ, K. C.; VIVAN, L. M.; GUIMARÃES, H. O.; CARVALHAIS, T. First reported occurrence of Helicoverpa armigera (Hubner) (Lepidoptera: Noctuidae) in Brazil, Pesquisa Agropecuária Tropical, v. 43, n. 1, p. 110-113, 2013. http://dx.doi.10.1590/S1983-40632013000100015.

DE BORTOLI, S. A.; MURATA, A. T.; DE BORTOLI, C. P.; MAGALHÃES, G. O.; DIBELLI, W. Aspectos nutricionais e preferência da lagarta-da-soja, Anticarsia gemmatalis Hüebner, 1818 (Lepidoptera: Noctuidae) em genótipos de soja com e sem injúria. Comunicata Scientia, v. 2, n. 3, p. 149-155, 2011.

DIDONET, J.; FRAGOSO, D. B.; PELUZIO, J. M. SANTOS, G. R. Flutuação Populacional de Pragas e seus inimigos naturais em Soja no projeto Rio Formoso - Formoso do Araguaia - TO, Brasil, Acta Amazonica, v. 28, n. 1, p. 67-74, 1998. https://doi.org/10.1590/1809-43921998281074

EMBRAPA. Ações emergenciais propostas pela Embrapa para o manejo integrado de Helicoverpa spp. em áreas agrícolas, v. 23, p. 1-12, 2013. http://www.agricultura.gov.br/arq_editor/ManejoHelicoverpa\%20(2).pdf. Acessed 25 jul 2016.

FORMENTINI, A. C.; SOSA-GÓMEZ, D. R.; PAULA-MORAES, S. V.; BARROS, N. M.; SPECHT, A. Lepidoptera (Insecta) associated with soybean in Argentina, Brazil, Chile and Uruguay, Ciência Rural, v. 45, n. 12, p. 2113-2120, 2015. http://dx.doi.10.1590/0103-8478cr20141258.

FREITAS, M. C. M. A. Cultura da soja no Brasil: o crescimento da produção brasileira e o surgimento de uma nova fronteira agrícola, Enciclopedia Biosfera, v. 7, n. 12, p. 1-12, 2011.

HOFFMANN-CAMPO, C. B.; CORRÊA-FERREIRA, B. S.; MOSCARDI, F. Soja: Manejo Integrado de Insetos e outros Artrópodes-Pragas, Embrapa Soja, Brasília, DF, v. 1, p. 1-859, 2012.

HOFFMANN-CAMPO, C. B.; MOSCARDI, F.; CORREAA-FERREIRA, B. S.; OLIVEIRA, L. J.; SOSAGOMEZ, D. R.; PANIZZI, A. R.; CORSO, I. C.; GAZZONI, D. L.; OLIVEIRA, E. B. Pragas da soja no Brasil e seu manejo integrado, Circular Técnica, Londrina: Embrapa Soja, v. 30, p. 1-70, 2000.

MACDONALD, K. P.; BACH, C. E. Resistance and tolerance to herbivory in Salix cordata are affected by different environmental factores, Ecological Entomology, Oxford, v. 30, n. 5, p. 585-589, 2005.

http://dx.doi:10.1111/j.0307-6946.2005.00729.x

MARSARO, J. R. A. L.; PEREIRA, P. R. V. S.; SILVA, W. R. S.; GRIFFEL, S. C. P. Flutuação populacional de insetos-praga na cultura da soja no Estado de Roraima, Ciências Agrárias e Ambientais, Curitiba, v. 8, n. 1, p. 71-76, 2010.

MOSCARDI, F.; BUENO, A. F.; SOSA-GÓMEZ, D. R.; ROGGIA, S.; HOFFMANN-CAMPO, C. B.; POMARI, A. F.; CORSO, I. C.; YANO, S. A. C. Artrópodes que atacam as folhas da soja. Embrapa, Brasil, p. 213-334, 2012. 
PASCHOLATI, S. F.; LEITE, B.; STANGARLIN, J. R. Interação Planta Patógeno - fisiologia, Bioquímica e Biologia Molecular. 1'. ed. Piracicaba, v. 13, p. 305-346, 2008.

POGUE, M. G. World Spodoptera data base (Lepidoptera: Noctuidae), United States Department of Agriculture, United States, v. 42, p. 1-11, 1995.

PRAÇA, L. B.; SILVA NETO, S. P.; MONNERAT, R. G. Anticarsia gemmatalis Hübner, 1818 (Lepidoptera: Noctuidae): biologia, amostragem e métodos de controle. Brasília: Embrapa Recursos Genéticos e

Biotecnologia, v. 1, p. 1-18, 2006.

RIFFEL, C. T.; GARCIA, M. S.; SANTI, A. L.; BASSO, C. J.; DELLA FLORA, L. P.; CHERUBIN, M. R.; EITELWEIN, M. T. Densidade amostral aplicada ao monitoramento georreferenciado de lagartas desfolhadoras na cultura da soja. Rural Science, Santa Maria, v. 1, p. 1-8, 2012. http://dx.doi.org/10.1590/S0034737X2011000600012.

SANTOS, E. R.; BARROS, H. B.; FERRAZ, E. C.; CELLA, A. J. S.; CAPONE, A.; SANTOS, A. F.; FIDELIS, R. R. Divergência entre genótipos de soja, cultivados em várzea irrigada, Revista Ceres, v. 58, n. 6 , p. 755-764, 2011. http://dx.doi.10.1590/S0034-737X2011000600012.

SAS INSTITUTE INC. SAS/STAT®. User's Guide. 2. ed. Cary, NC: SAS Institute Inc, 1999. 454 p.

SOSA-GÓMEZ, D. R. Seletividade de agroquímicos para fungos entomopatogênicos. Disponível em: http://www.cnpso.embrapa.br/download/artigos/seletiv_fung.pdf, 2006. Acessed 25 jul 2016.

SOSA-GÓMEZ, D. R.; DELPIN, K. E.; MOSCARDI, F.; NOZAKI, M. H. The impact of fungicides on Nomuraea rileyi (Farlow) Samson epizootics and on populations of Anticarsia gemmatalis Hübner (Lepidoptera: Noctuidae), on soybean, Neotropical Entomology, v. 32, p. 287-291, 2003. http://dx.doi.org/10.1590/S1519-566X2003000200014.

WALTERS, D.; NEWTON, A.; LYON, G. Induced resistance for plant defence - a sustainable approach to crop protection. Oxford: Blackwell, 2007, 352 p. https://doi.org/10.1002/9780470995983 